\title{
Inwentaryzacja zasobów martwego drewna w planach urządzenia lasu i w wielkoobszarowej inwentaryzacji stanu lasów
}

\author{
ANDRZEJ TALARCZYK
}

\begin{abstract}
TALARCZYK, A. 2020. Inventorying deadwood in forest management plans and in the National Forest Inventory. Fragmenta Floristica et Geobotanica Polonica 27(1): 95-118. Kraków. e-ISSN 2449-8890, ISSN 1640-629X.

ABSTRACT: Systematic inventories of deadwood in Polish forests are carried out as part of two separate activities: the National Forest Inventory (NFI), and periodic inventories of forest stands for the purpose of forest management plans preparation. These activities differ in their objectives, methodology and scope. The NFI has been conducted continuously since 2005 , covering the whole country; its third series was completed in 2019. Measurements of deadwood as part of forest management planning have been carried out since 2012; data for 53.3\% of the forest districts have been analysed (229 out of 430), covering 3,989,575 ha of forest. Data from both inventories are collected in the Forest Data Bank. A comparison of the results of both inventories for the same areas has shown similarities, but also differences that affect their interpretation and use for other studies. The volume of deadwood in Polish forests is relatively low as compared to guidelines in the literature, but a positive trend has been observed in recent years.
\end{abstract}

KEY WORDS: deadwood, forest management planning, National Forest Inventory (NFI)

A. Talarczyk, Biuro Urzqdzania Lasu i Geodezji Leśnej, ul. Leśników 21, 05-090 Sękocin Stary, Polska; e-mail: Andrzej.Talarczyk@zarzad.buligl.pl

\section{WSTEP}

Drewno martwe pełni kluczową rolę w wielu procesach i funkcjach ekosystemów leśnych, dlatego jego stan powinien być monitorowany (HARMON i in. 1986; KRAJICK 2001; SOLON 2002). Pierwsze inwentaryzacje i monitoringi drewna martwego miały miejsce w latach 60. XX w. wraz z pojawieniem się nowoczesnej ochrony przeciwpożarowej, w której niezbędna była szybka terenowa ocena ilości substancji palnej w lesie. Inwentaryzacje te nie miały w większości krajów systematycznego charakteru. Dopiero po pojawieniu się kompleksowych inicjatyw w zakresie monitorowania lasów w latach 90. (np. Deklaracja z Santiago) i wymogów dotyczących raportowania emisji gazów cieplarnianych dla sektora LULUCF w Ramowej konwencji Narodów Zjednoczonych w sprawie zmian klimatu, zainicjowano pierwsze inwentaryzacje drewna martwego o zasięgach ogólnokrajowych (WoODALL $i$ in. 2019). W pierwszej dekadzie bieżącego stulecia, co najmniej 
30 krajów uwzględniało drewno martwe w swoich wielkoobszarowych inwentaryzacjach lasu (WoODALL i in. 2009). Ich celem była już nie tylko ocena zagrożenia pożarowego, ale także szacowanie bilansu węgla i monitorowanie bioróżnorodności (RoNDEUX \& SANCHEZ 2010).

W Polsce do niedawna badania nad występowaniem drewna martwego były prowadzone w sposób fragmentaryczny, często na terenach przyrodniczo cennych, np. Puszczy Białowieskiej (FALIŃSKI 1978; BOBIEC i in. 2000; BOBIEC 2002) i terenach górskich (ZIELONKA \& NiKLASSON 2001), aczkolwiek wykonywano także analizy w lasach gospodarczych (WOLSKI 2003). Inwentaryzacje na większą skalę zaczęto prowadzić na początku XXI w. Aktualnie drewno martwe na terenach leśnych jest inwentaryzowane w sposób systematyczny w ramach dwóch niezależnych działań: 1) inwentaryzacji drzewostanów prowadzonej podczas sporządzania planu urządzenia lasu (PUL) dla nadleśnictwa - w lasach Skarbu Państwa pozostających pod nadzorem Państwowego Gospodarstwa Leśnego Lasy Państwowe oraz 2) Wielkoobszarowej Inwentaryzacji Stanu Lasów (WISL) - w lasach wszystkich form własności. Ponadto Polska jest uczestnikiem programu monitoringu lasów ICP Forests; dane dla tego programu zbierane są na niektórych powierzchniach próbnych WISL, gdyż siatka pomiarowa WISL oparta jest na siatce ICP Forests poziomu I (TALARCZYK 2014; PulETTI i in. 2019).

Celem pracy było: 1) zapoznanie czytelnika z metodyką dwóch najważniejszych krajowych inwentaryzacji martwego drewna oraz 2) przedstawienie i porównanie wyników tych inwentaryzacji w nadleśnictwach Lasów Państwowych dla lat 2013-2019.

\section{MATERIAEY I METODY}

\section{Inwentaryzacja drewna martwego podczas sporządzania planu urządzenia lasu (PUL)}

\section{Metodyka inwentaryzacji}

W trakcie przygotowania planu urządzenia lasu dla nadleśnictwa, przeprowadzana jest inwentaryzacja miąższości obrębu leśnego statystyczną metodą reprezentacyjną, z zastosowaniem warstw gatunkowo-wiekowych oraz losowego wyboru powierzchni próbnych. Jej celem jest uzyskanie wiarygodnej informacji o aktualnym rozmiarze zasobów drzewnych w urządzanym obrębie leśnym i nadleśnictwie. Inwentaryzacji podlegają drzewostany od 21 lat wzwyż, w których średnia wysokość gatunku panującego jest równa lub większa od $7 \mathrm{~m}$. Do pomiaru miąższości przyjmuje się następujący zbiór drzewostanów:

- od 21 lat wzwyż dla sosny w klasie bonitacji Ia-III i dęba w klasie bonitacji I-III oraz dla świerka I i II bonitacji, a także dla: modrzewia, jawora, jesionu, brzozy, olszy, topoli, osiki;

- od 31 lat wzwyż dla sosny IV i V bonitacji, dla świerka III-V bonitacji, dla jodły i buka I-III bonitacji oraz dla dęba IV bonitacji;

- od 41 lat wzwyż dla jodły i buka IV i V bonitacji.

Pomiary wykonywane są na wylosowanych, kołowych powierzchniach próbnych. Wielkości powierzchni próbnych są zróżnicowane w zależności od klasy i podklasy wieku gatunku panującego:

1) IIa (21-30 lat) - 0,005 ha (promień $r=3,99 \mathrm{~m}$ ),

2) IIb (31-40 lat) - 0,01 ha (promień $r=5,64 \mathrm{~m})$,

3) IIIa i IIIb (41-60 lat) - 0,02 ha (promień $r=7,98 \mathrm{~m}$ ), 
4) IVa i IVb (61-80 lat) - 0,03 ha (promień $r=9,77 \mathrm{~m})$,

5) Va i Vb (81-100 lat) - 0,04 ha (promień $r=11,28 \mathrm{~m}$ ),

6) VI i starsze (powyżej 100 lat) oraz klasa odnowienia (KO), klasa do odnowienia (KDO) i drzewostany o budowie przerębowej (BP) $-0,05$ ha (promień $r=12,62 \mathrm{~m}$ ).

Na co dziesiątej powierzchni próbnej, założonej według opisanego powyżej schematu, wylosowanej przez program Taksator (TAXUS IT 2020), wykonywane są pomiary drewna martwego.

Generalnie przyjmowaną zasadą jest pomiar tylko martwych drzew albo fragmentów drewna martwego, które można jednoznacznie zidentyfikować jako pochodzące z obrębu powierzchni próbnej. Co więcej, instrukcja przewiduje, że pomiarowi podlegają także te części martwych drzew lub drewna martwego, które znajdują się poza powierzchnią próbną, ale można je przypisać do drzewa rosnącego w granicach powierzchni próbnej.

Posusz stojący (całe drzewa martwe) i złomy podlegają pomiarowi, jeśli ich pierśnica przekracza $70 \mathrm{~mm}$. Rejestruje się dla nich gatunek, pierśnicę oraz wysokość drzewa (długość strzały), przy czym w przypadku złomów nie uwzględnia się części złomów poniżej średnicy $70 \mathrm{~mm}$.

Drewno martwe leżące, zaklasyfikowane jako pochodzące z powierzchni próbnej, podlega pomiarowi, jeśli jego średnica w grubszym końcu przekracza $100 \mathrm{~mm}$ w korze. Rejestruje się wówczas gatunek, długość, średnicę mierzoną w połowie długości, przy czym długość mierzy się tylko do miejsca, w którym średnica kłody wynosi 70 mm (PGL LP 2012).

\section{Dostepne dane}

Drewno martwe na powierzchniach próbnych, zakładanych w ramach inwentaryzacji na potrzeby sporządzania planu urządzenia lasu (zwanej dalej ,inwentaryzacją PUL”), jest mierzone od 2012 r. (z tego roku pochodzi najstarsza baza PUL zawierająca takie dane). O przeprowadzeniu pomiarów drewna martwego decyduje komisja założeń planu.

W analizach uwzględniono 233 bazy urządzeniowe, dostępne w strukturze i formacie programu TAKSATOR, przewidzianej przez część 1 „Instrukcji urządzania lasu” (PGL LP 2012; TAXUS IT 2020). Trzy bazy dla nadleśnictw Puszczy Białowieskiej nie zostały uwzględnione ze względu na występującą w nich specyficzną sytuację klęski gradacji kornika drukarza, co zniekształciłoby wyniki (nadleśnictwa 01-02 Białowieża, 01-05 Browsk i 01-14 Hajnówka). Martwe drewno nie było obliczone w trakcie prac urządzeniowych także w bazie Nadleśnictwa Pomorze (01-22), która z tego powodu również została wyłączona $\mathrm{z}$ analizy.

Całkowita powierzchnia lasów w zarządzie PGL LP wynosi 7114 617,67 ha (GUS 2019). Ogółem przeanalizowano wyniki pomiarów martwego drewna dla 53,3\% liczby nadleśnictw ( 229 z 430). W układzie powierzchniowym była to powierzchnia 3989575 ha (229 nadleśnictw), czyli 56,0\% powierzchni wszystkich lasów w zarządzie PGL LP. Rozmieszczenie analizowanych nadleśnictw przedstawia rycina 1.

\section{Inwentaryzacja drewna martwego w Wielkoobszarowej Inwentaryzacji Stanu Lasów (WISL)}

\section{Metodyka inwentaryzacji}

W ramach WISL pomiary wykonywane są na kołowych powierzchniach próbnych, rozmieszczonych w traktach po pięć powierzchni rozlokowanych w regularnej siatce $4 \times 4 \mathrm{~km}$ (TALARCZYK 2014). W I (2005-2009) i II (2010-2014) cyklu WISL wielkość powierzchni próbnej była uzależniona od wieku drzewostanu i wynosiła 200, 400 lub $500 \mathrm{~m}^{2}$ (IBL 2010). Od III cyklu (2015-2019) powierzchnie próbne mają stałą wielkość $400 \mathrm{~m}^{2}$ (IBL 2014).

W WISL drewno martwe inwentaryzowane jest na powierzchniach próbnych w następujących klasach: drzewa (drewno) leżące - ścięte, drzewa (drewno) leżące - wywrócone, drewno leżące - odłamane, drzewa stojące (posusz), złomy stojące. Inwentaryzowane jest tylko drewno martwe, tj. drzewa leżące i fragmenty drewna, które przecinają granicę powierzchni próbnej - mierzone są tylko ich części zlokalizowane 


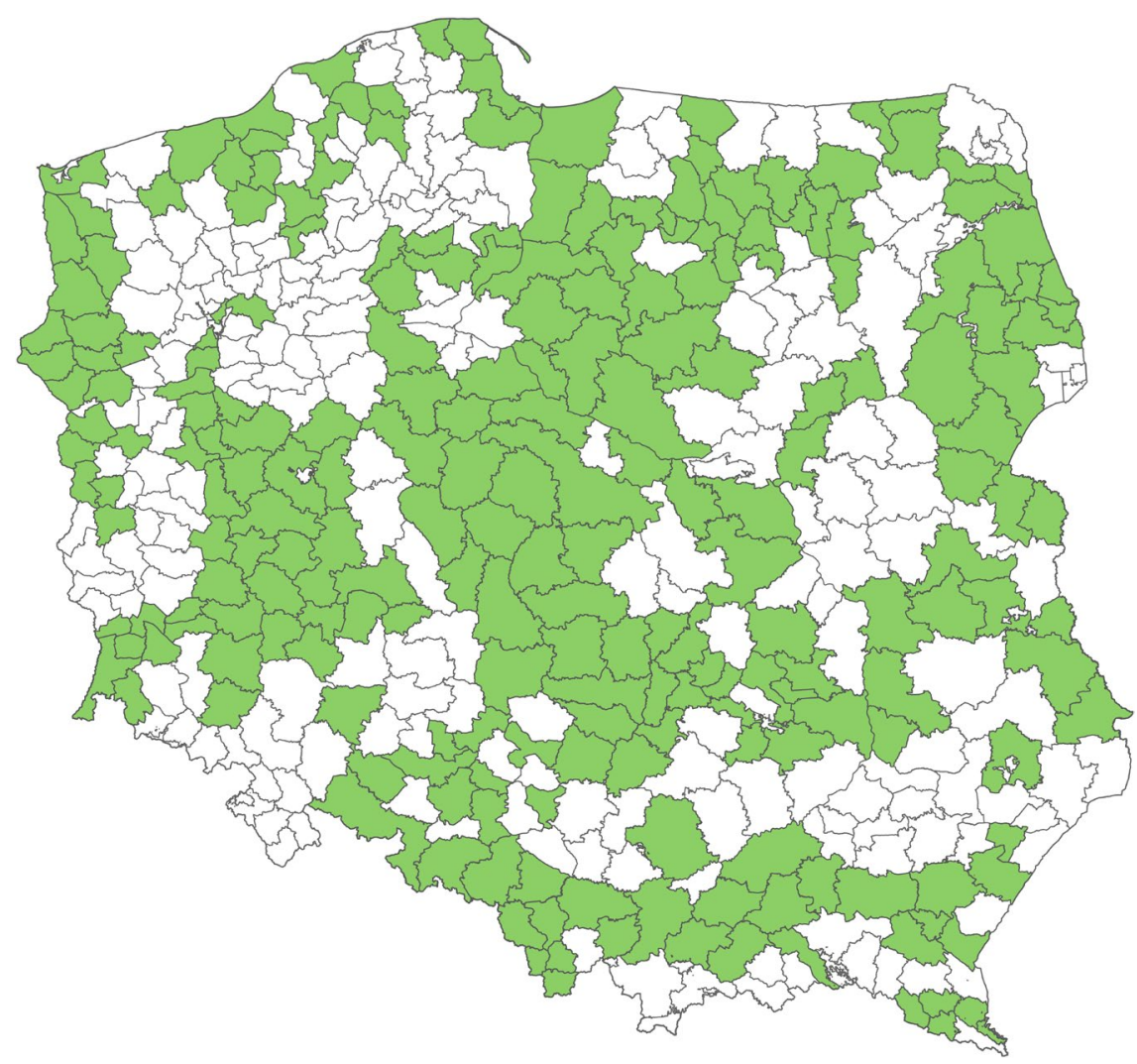

Ryc. 1. Rozmieszczenie nadleśnictw Lasów Państwowych, dla których analizowano dane o drewnie martwym znajdujące się w bazach PUL

Fig. 1. Locations of state forest districts for which deadwood data in stand-wise forest inventory databases have been analysed

wewnątrz powierzchni próbnej, o minimalnej długości $50 \mathrm{~cm}$, których średnica w grubszym końcu jest większa niż $100 \mathrm{~mm}$ w korze ( $80 \mathrm{~mm}$ bez kory). Długości fragmentów drewna martwego mierzone są do miejsca, w którym średnica w korze wynosi $70 \mathrm{~mm}$ (50 mm bez kory), albo do granicy powierzchni próbnej.

Dla całych drzew stojących i leżących, w całości zlokalizowanych w obrębie powierzchni próbnej, mierzona jest pierśnica i wysokość (długość strzały), natomiast w przypadku drzew stojących złamanych mierzona jest zarówno pierśnica, jak i średnica w połowie wysokości. Ponadto, rejestrowany jest gatunek, klasa i stopień rozłożenia (IBL 2014).

\section{Dostęne dane}

Pomiary drewna martwego są wykonywane w ramach WISL od początku, tj. od $2005 \mathrm{r}$. W I cyklu WISL (2005-2009) na gruntach leśnych założono 28909 powierzchni próbnych, w II cyklu (2010-2014) - 29523 (PGL LP 2015), a w III cyklu (2015-2019) - 30578 powierzchni próbnych (dane niepublikowane). Dodatkowo, w III cyklu założono 3815 powierzchni próbnych na gruntach niebędących lasem według Ewidencji Gruntów i Budynków, ale porośniętych przez drzewostany o parametrach analogicznych do tych z definicji lasu, zawartej w ustawie o lasach (UsTAwA 1991) lub definicji lasu używanej w raportowaniu FRA FAO (FAO 2012). 


\section{Obliczenia z powierzchni próbnych PUL}

Obliczenia miąższości pojedynczych fragmentów drewna martwego wykonywane były za pomocą programu Taksator (TAXUS IT 2020), w którym zaimplementowany został następujący algorytm (A. Konieczny, K. Mroczek, informacja osobista):

- posusz stojący (kod POSUSZ): w sposób analogiczny do drzew żywych, tj. przy użyciu empirycznie wyprowadzonych funkcji Gompertza, odwzorowujących matematycznie tablice zasobności i przyrostu drzewostanów, zestawione przez B. Szymkiewicza (SZYMKIEwICZ 2001; TALARCZYK 2014);

- złomy (kod ZŁOM): jeśli wysokość złomu nie przekracza 1,3 m stosowany jest wzór na objętość walca z użyciem wysokości złomu i jego średnicy w połowie wysokości; w przeciwnym wypadku używany jest bardziej skomplikowany algorytm, polegający na wyliczeniu teoretycznej wysokości drzewa na podstawie innych drzew tego samego gatunku na powierzchni próbnej (a w przypadku ich braku na innych powierzchniach próbnych), obliczeniu miąższości teoretycznej strzały, obliczeniu na podstawie wzorów sekcyjnych (KŁAPEĆ i in. 2005) miąższości 15 sekcji strzały o równych długościach, a następnie zsumowaniu miąższości sekcji do miejsca złamania (na podstawie wysokości złomu);

- pozostałe rodzaje fragmentów drewna martwego: stosowany jest wzór na objętość walca z użyciem długości fragmentu i pola przekroju w połowie długości.

Zasobność drewna martwego na pojedynczej powierzchni próbnej obliczano za pomocą wzoru:

$$
\widehat{v}_{\imath}=\frac{\sum_{j=1}^{k_{i}} v_{i j}}{p_{i}} \times 10000
$$

gdzie:

$\widehat{v_{l}}$ - zasobność drewna martwego na powierzchni próbnej $i\left(\mathrm{~m}^{3} / \mathrm{ha}\right)$

$v_{i j}$ - miąższość pojedynczego fragmentu drewna martwego $j$ na powierzchni próbnej $i\left(\mathrm{~m}^{3}\right)$

$k_{i}$ - liczba fragmentów drewna martwego na powierzchni próbnej $i$

$p_{i}$ - pole powierzchni próbnej $i\left(\mathrm{~m}^{2}\right)$

$j \quad$ - indeks danego fragmentu drewna martwego na powierzchni próbnej

$i \quad$ - indeks danej powierzchni próbnej

Miąższość drewna martwego w jednostce inwentaryzacyjnej obliczano następująco:

$$
V_{D}=\frac{\sum_{i=1}^{n}\left(\widehat{v}_{l} \times p_{i}\right)}{\sum_{i=1}^{n} p_{i}} \times P_{D}
$$

gdzie:

$V_{D}$ - miąższość drewna martwego w danej domenie $D\left(\mathrm{~m}^{3}\right)$

$\widehat{v}_{l}$ - miąższość drewna martwego na powierzchni próbnej $i \mathrm{w}$ przeliczeniu na jednostkę powierzchni $\left(\mathrm{m}^{3} / \mathrm{ha}\right)$

$p_{i}$ - wielkość danej powierzchni próbnej $i\left(\mathrm{~m}^{2}\right)$

$P_{D}$ - powierzchnia danej jednostki inwentaryzacyjnej $D$ (ha)

$n$ - liczba powierzchni próbnych

$i \quad$ - indeks danej powierzchni próbnej

Standardowy błąd procentowy szacowania miąższości określono wzorem:

$$
S P E=\frac{W}{\sqrt{\sum_{i=1}^{n} p_{i}}}=\frac{\frac{\sqrt{\frac{\sum_{i=1}^{n}\left(\widehat{v}_{l}^{2} \times p_{i}\right)}{n-1}-\frac{\sum_{i=1}^{n} p_{i}}{n-1}\left(\frac{\sum_{i=1}^{n} \widehat{v}_{l} \times p_{i}}{\sum_{i=1}^{n} p_{i}}\right)^{2}}}{\frac{\sum_{i=1}^{n}\left(\widehat{v}_{l} \times p_{i}\right)}{\sum_{i=1}^{n} p_{i}}}}{\sqrt{\sum_{i=1}^{n} p_{i}}} \times 100 \%
$$


gdzie:

$S P E$ - błąd procentowy określania miąższości

$W$ - współczynnik zmienności

$\widehat{v}_{l}$ - miąższość drewna martwego na powierzchni próbnej $i \mathrm{w}$ przeliczeniu na jednostkę powierzchni $\left(\mathrm{m}^{3} / \mathrm{ha}\right)$

$p_{i}$ - wielkość danej powierzchni próbnej $i\left(\mathrm{~m}^{2}\right)$

$n$ - liczba powierzchni próbnych

$i \quad$ - indeks danej powierzchni próbnej

Granice przedziału ufności $(C I)$ przy poziomie istotności $p=0,05$ obliczono w sposób przybliżony, zakładając rozkład normalny, według wzoru:

$$
C I=V_{D} \pm S P E \times 1,96
$$

\section{Obliczenia z powierzchni próbnych WISL}

Obliczenia miąższości pojedynczych fragmentów drewna martwego wykonywane były za pomocą oprogramowania WISL, w którym zaimplementowany jest następujący algorytm (BULIGL 2017):

- miąższość całych drzew martwych (posuszu): obliczana jest w sposób analogiczny do drzew żywych, tj. przy użyciu empirycznie wyprowadzonych funkcji Gompertza, odwzorowujących matematycznie tablice zasobności i przyrostu drzewostanów, zestawione przez B. Szymkiewicza (SZYMKIEWICZ 2001; TALARCZYK 2014);

- miąższość złomów i wszystkich leżących fragmentów drewna martwego obliczana według wzoru na objętość walca, na podstawie długości fragmentu i pola jego przekroju w połowie długości.

Zasobność drewna martwego na pojedynczej powierzchni próbnej obliczano za pomocą wzoru (1), przy czym obliczenia wykonywano nie dla całych powierzchni próbnych, lecz dla podpowierzchni wydzielonych zgodnie z metodyką inwentaryzacji.

Miąższość drewna martwego, standardowy błąd procentowy szacowania miąższości oraz przedziały ufności w jednostce inwentaryzacyjnej obliczano analogicznie jak w inwentaryzacji PUL: odpowiednio wzór (2), (3) i (4) - przy czym w miejsce $p$ (pola powierzchni próbnej) podstawiono $z$ (udział areału danej podpowierzchni w całej powierzchni próbnej).

\section{Zmiany zasobów drewna martwego}

Od ostatniego roku I cyklu WISL (2009 r.) dostępne są wyniki pomiarów drewna martwego na terenie całej Polski. Ponieważ WISL jest prowadzona w trybie ciągłym - co roku inwentaryzowane jest ponownie $20 \%$ powierzchni próbnych - wyniki szacowania zasobów drewna martwego mogą być corocznie aktualizowane. Porównano i zestawiono je dla lat 2009-2019. Należy zwrócić uwagę, że cykl WISL ma długość 5 lat, a w każdym roku inwentaryzowanych jest jedynie $20 \%$ powierzchni próbnych, a zatem wartości raportowane dla danego roku są w rzeczywistości wypadkową ze stanu rejestrowanego w ostatnich pięciu latach przed rokiem raportowania.

\section{Porównanie wyników inwentaryzacji drewna martwego z WISL i PUL}

Dostępne wyniki inwentaryzacji drewna martwego dla 229 nadleśnictw Lasów Państwowych, porównano do wyników otrzymanych z powierzchni próbnych WISL, założonych na gruntach Lasów Państwowych w analizowanych nadleśnictwach. Dla nadleśnictw podlegających analizie wyliczone zostały zasoby drewna martwego, biorąc jako dane źródłowe wyniki pomiarów na powierzchniach próbnych inwentaryzacji PUL lub powierzchniach próbnych WISL.

W związku z tym, że metodyka pomiarów drewna martwego na potrzeby PUL ogranicza zakładanie powierzchni próbnych do drzewostanów od II klasy wieku (powyżej 20 lat), dla porównania, obliczenia 
wykonano także na zbiorze powierzchni próbnych WISL założonych w drzewostanach o wieku gatunku panującego powyżej 20 lat. Średnia miąższość drewna martwego była obliczana w odniesieniu do 1 ha całej powierzchni leśnej nadleśnictwa (mimo braku pomiarów w I klasie wieku w inwentaryzacji PUL i wyeliminowania takich pomiarów ze zbioru danych inwentaryzacji WISL).

Porównano także jak kształtują się zasoby drewna martwego w lasach na obszarach sieci Natura 2000 w odniesieniu do innych lasów. Dane dotyczące powierzchni lasów objętych siecią Natura 2000 dostępne są tylko dla lasów w zarządzie PGL LP. Na terenie Lasów Państwowych znajdują się obszary Natura 2000 o powierzchni 2891 tys. ha (38,0\% powierzchni LP), w tym: 133 obszary ptasie (OSO), zajmujące powierzchnię 2217 tys. ha $(29,1 \%)$ oraz 708 obszarów o znaczeniu dla Wspólnoty (OZW), o łącznej powierzchni 1663 tys. ha (21,9\%) (PGL LP 2019). Całkowita powierzchnia zalesiona Lasów Państwowych na 31 grudnia 2018 r. wynosiła 7115 tys. ha (GUS 2019). W związku z brakiem analogicznych danych dla innych form własności, analizę zasobów drewna martwego w obszarach Natura 2000 wykonano jedynie dla lasów w zarządzie PGL LP.

\section{Analiza danych}

Dane analizowano w środowisku bazodanowym PostgreSQL 11 (PUL) i Microsoft SQL Server 2014 (WISL) za pomocą oprogramowania statystycznego R w wersji 3.50, Python w wersji 3.6.8 (www.python. org), w środowiskach IDE RStudio (rstudio.com) i Jupyter Notebook (jupyter.org). Wykresy zostały przygotowane z wykorzystaniem pakietów oprogramowania ggplot2 w wersji 3.2.1 (ggplot2.tidyverse.org), pandas w wersji 0.25 (pandas.pydata.org), matplotlib w wersji 3.1.2 (matplotlib.org) oraz seaborn w wersji 0.9.0 (seaborn.pydata.org).

\section{WYNIKI}

\section{Porównanie wyników inwentaryzacji drewna martwego z WISL i PUL}

\section{Liczba powierzchni próbnych}

W inwentaryzacji PUL, w nadleśnictwie przeciętnie mierzono drewno martwe na 269 powierzchniach (od 90 do 607, z medianą 231). W dwóch nadleśnictwach drewno martwe mierzono na wszystkich założonych taksacyjnych powierzchniach próbnych (Nadleśnictwo Strzelce Opolskie, 02-29 - 2750, Nadleśnictwo Smolarz, 10-28 - 1829). Ze względu na różnice w metodyce inwentaryzacji, w przypadku WISL liczby założonych powierzchni próbnych na nadleśnictwo były znacznie mniejsze, przeciętnie wynosiły 48 (od 2 do 96, z medianą 48). Na rycinie 2 przedstawiono porównanie liczby powierzchni próbnych założonych na obszarze danego nadleśnictwa.

W inwentaryzacji PUL klasyfikuje się fragmenty drewna martwego w zależności od ich charakteru (pochodzenia i wyglądu). Rozkłady ich długości przedstawia rycina 3, a średnicy - rycina 4. Z kolei na rycinie 5 porównano rozkład liczby sztuk drewna martwego w klasach długości. Liczba wszystkich zinwentaryzowanych fragmentów drewna martwego, leżącego na obszarze analizowanych nadleśnictw, jest większa w przypadku inwentaryzacji PUL niż w inwentaryzacji WISL, szczególnie tych o długości 0-3 m, a także w mniejszym stopniu, od $10 \mathrm{~m}$ wzwyż. Natomiast w przypadku drewna martwego stojącego, w inwentaryzacji WISL zarejestrowano więcej fragmentów, szczególnie o długości do $15 \mathrm{~m}$.

Po przeanalizowaniu danych z III cyklu WISL (Ryc. 6) nie stwierdzono korelacji pomiędzy liczbą fragmentów a zasobnością drewna martwego na pojedynczej powierzchni próbnej. Po podzieleniu zbioru powierzchni próbnych na grupy o określonej liczbie sztuk 


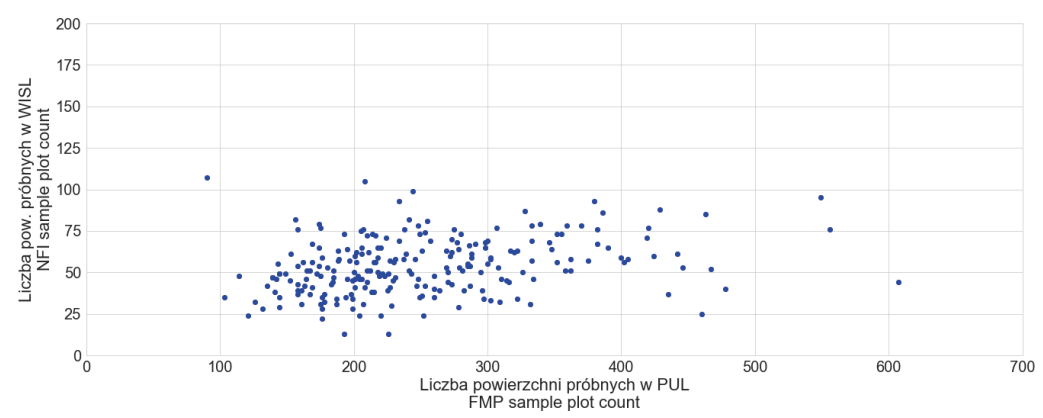

Ryc. 2. Porównanie liczby powierzchni próbnych w nadleśnictwie pomiędzy PUL a WISL

Fig. 2. Comparison of the number of sample plots in a forest district between stand-wise inventories and the NFI
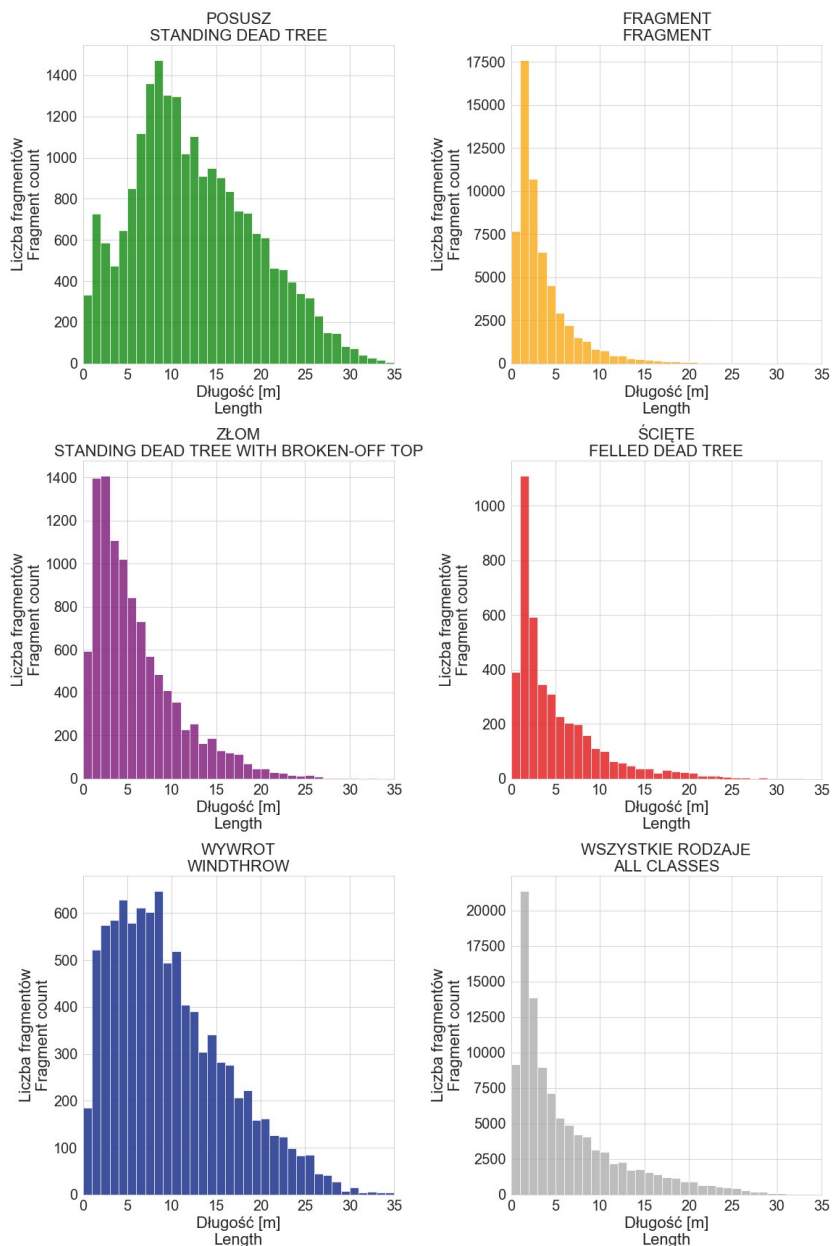

Ryc. 3. Częstość występowania fragmentów drewna martwego o określonej długości na powierzchniach próbnych inwentaryzacji PUL

Fig. 3. Incidence of deadwood fragments, by length, in stand-wise inventory sample plots (PUL) 

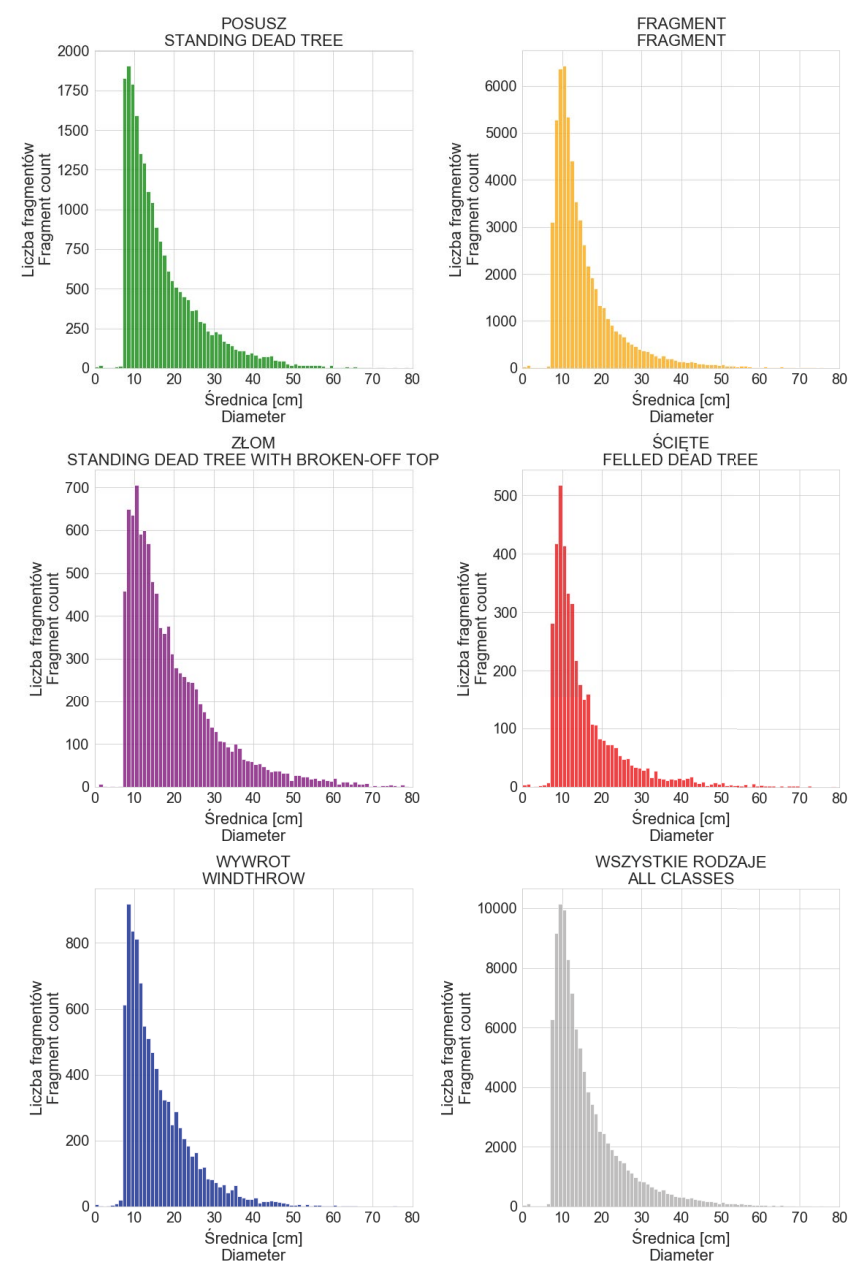

Ryc. 4. Częstość występowania fragmentów drewna martwego o określonej średnicy na taksacyjnych powierzchniach próbnych inwentaryzacji PUL

Fig. 4. Incidence of deadwood fragments, by diameter, in stand-wise inventory sample plots (PUL)

drewna martwego na powierzchni, zaobserwowano dodatnią korelację (z zastosowaniem wielomianu drugiego stopnia) pomiędzy liczbą sztuk a średnią zasobnością drewna martwego w danej grupie - przede wszystkim dla drewna martwego stojącego $(r=0,64)$ oraz dla zsumowanej liczby drewna martwego stojącego i leżącego $(r=0,43)$.

\section{Zasoby drewna martwego}

Porównanie wyników obliczeń zasobności drewna martwego pomiędzy inwentaryzacją PUL a inwentaryzacją WISL dla poszczególnych nadleśnictw przedstawia rycina 7. W związku z tym, że eksploracja wykazała skośny rozkład danych, analizę przeprowadzono na danych transformowanych logarytmicznie. Korelacja miąższości martwych drzew, określonej w inwentaryzacji PUL i w inwentaryzacji WISL, była umiarkowana: współczynnik 

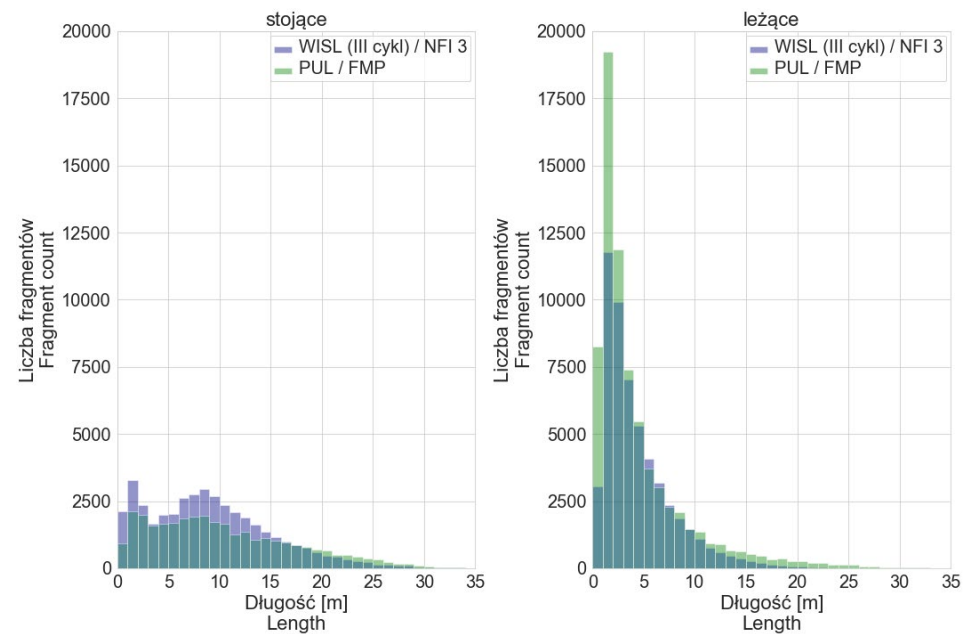

Ryc. 5. Częstość występowania fragmentów drewna martwego o określonej długości

Fig. 5. Incidence of deadwood fragments, by length
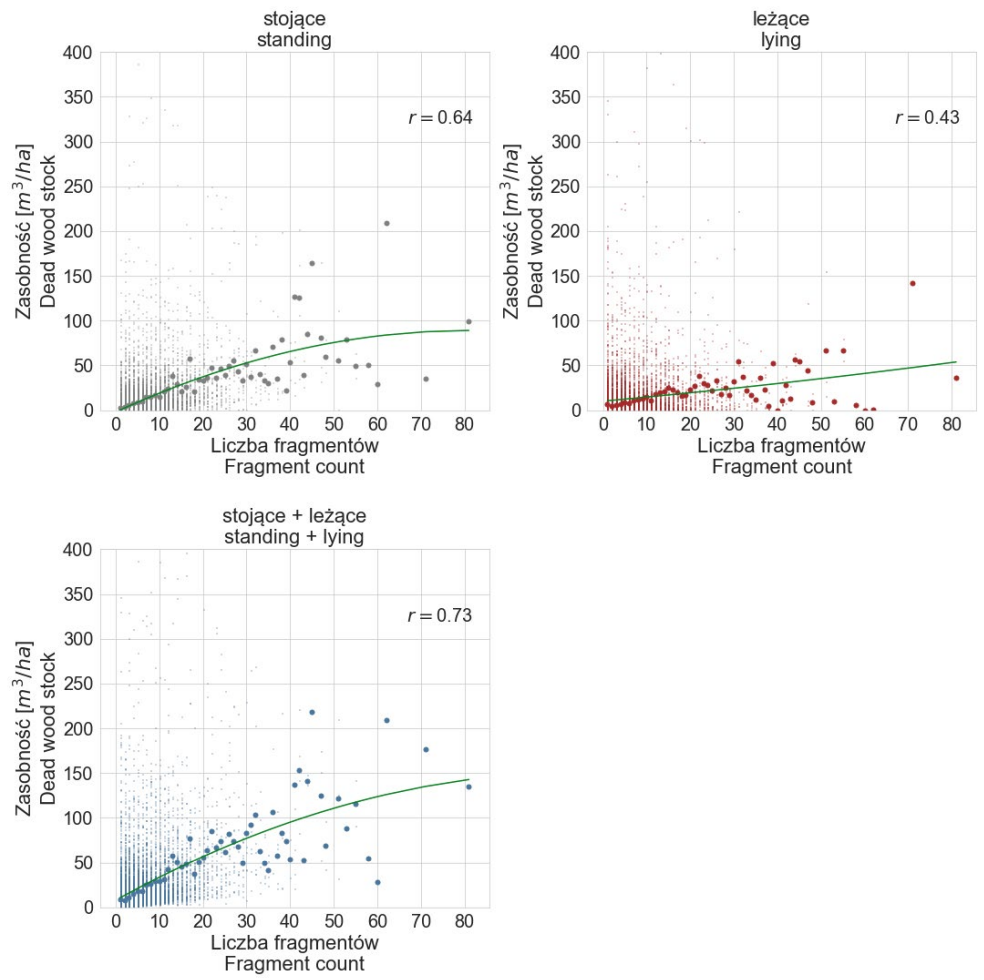

Ryc. 6. Porównanie liczby fragmentów z wyliczoną zasobnością drewna martwego na pojedynczych powierzchniach próbnych WISL

Fig. 6. Comparison of number of fragments to calculated deadwood stock in individual sample plots in the NFI 

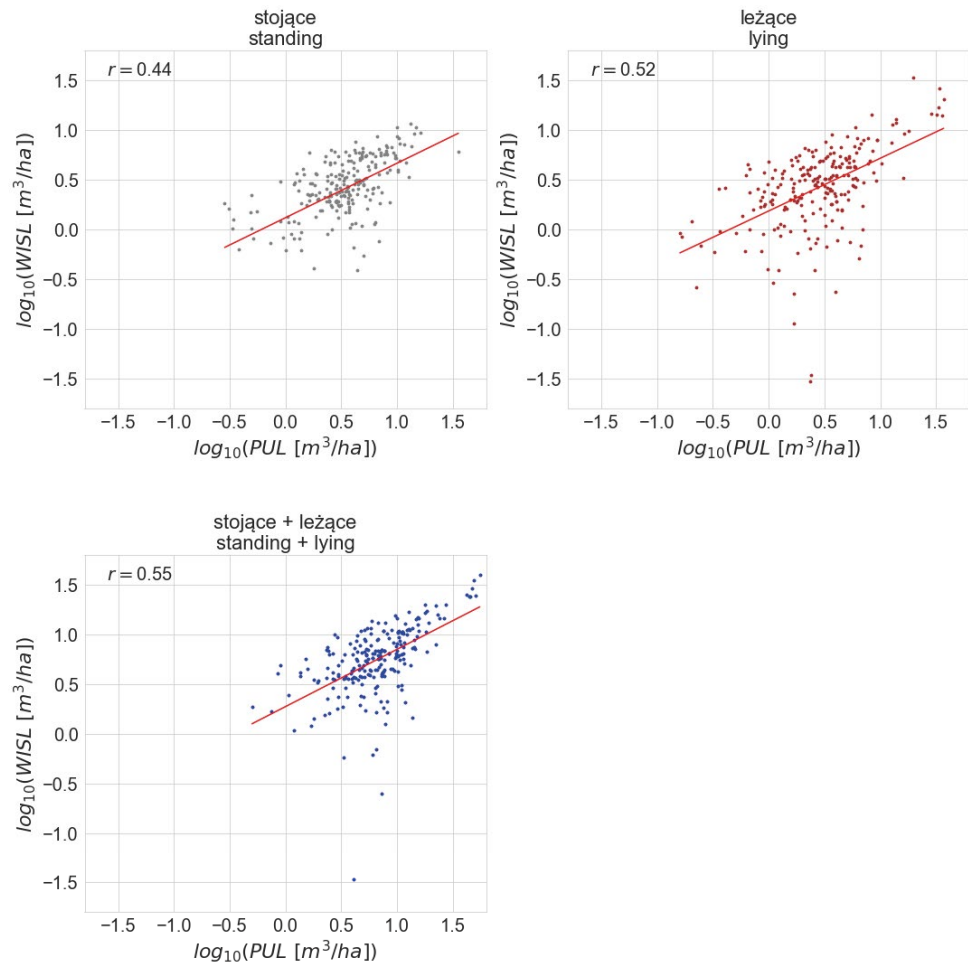

Ryc. 7. Porównanie zasobności drewna martwego w nadleśnictwach pomiędzy inwentaryzacją PUL a WISL

Fig. 7. Comparison of the deadwood stock in forest districts between the stand-wise inventories and the NFI

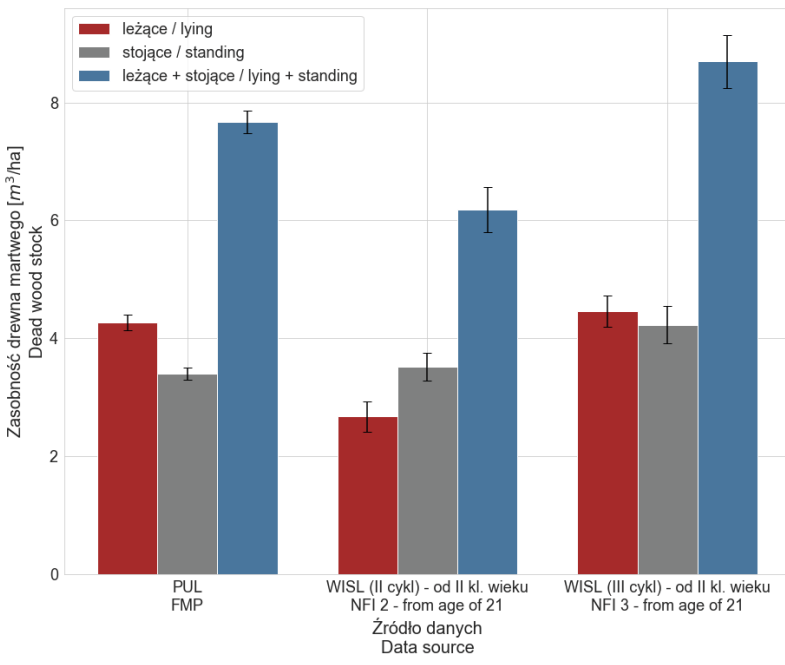

Ryc. 8. Zasobność drewna martwego na obszarze nadleśnictw podlegających analizie

Fig. 8. Deadwood stock within the analysed forest districts 
Tabela 1. Zasoby drewna martwego na obszarze nadleśnictw podlegających analizie

Table 1. Deadwood stock within the analysed forest districts

\begin{tabular}{|c|c|c|c|c|c|c|}
\hline \multirow{2}{*}{$\begin{array}{l}\text { Zbiór powierzchni próbnych } \\
\text { (Sample plot set) }\end{array}$} & \multicolumn{2}{|c|}{$\begin{array}{l}\text { Drewno martwe stojące } \\
\text { (Standing deadwood) }\end{array}$} & \multicolumn{2}{|c|}{$\begin{array}{c}\text { Drewno martwe leżące } \\
\text { (Lying deadwood) }\end{array}$} & \multicolumn{2}{|c|}{$\begin{array}{l}\text { Drewno martwe razem } \\
\text { (Total deadwood) }\end{array}$} \\
\hline & $\mathrm{m}^{3}$ & $\mathrm{~m}^{3} / \mathrm{ha}$ & $\mathrm{m}^{3}$ & $\mathrm{~m}^{3} / \mathrm{ha}$ & $\mathrm{m}^{3}$ & $\mathrm{~m}^{3} / \mathrm{ha}$ \\
\hline $\begin{array}{l}\text { WISL (II cykl) - wszystkie } \\
\text { klasy wieku } \\
\text { (NFI2 - all age classes) }\end{array}$ & 11939298 & 3,04 & 9319894 & 2,37 & 21259192 & 5,40 \\
\hline $\begin{array}{l}\text { WISL (II cykl) - od II klasy } \\
\text { wieku } \\
\text { (NFI2 - from age class II } \\
\text { upwards) }\end{array}$ & 13837994 & 3,52 & 10509999 & 2,67 & 24347993 & 6,19 \\
\hline $\begin{array}{l}\text { WISL (III cykl) - wszystkie } \\
\text { klasy wieku } \\
\text { (NFI3 - all age classes) }\end{array}$ & 14418995 & 3,67 & 16159331 & 4,11 & 30578326 & 7,77 \\
\hline $\begin{array}{l}\text { WISL (III cykl) - od II klasy } \\
\text { wieku } \\
\text { (NFI3 - from age class II } \\
\text { upwards) }\end{array}$ & 16647230 & 4,23 & 17556599 & 4,46 & 34203829 & 8,70 \\
\hline $\begin{array}{l}\text { PUL - od II klasy wieku } \\
\text { (FMP inventory - from age } \\
\text { class II upwards) }\end{array}$ & 13367574 & 3,40 & 16800319 & 4,27 & 30167894 & 7,67 \\
\hline
\end{tabular}

Tabela 2. Standardowy błąd procentowy szacowania miąższości drewna martwego na obszarze nadleśnictw podlegających analizie

Table 2. Standard percentage error of deadwood volume estimation within the analysed forest districts

\begin{tabular}{l|c|c|c|c}
\hline \hline $\begin{array}{l}\text { Zbiór powierzchni próbnych } \\
\text { (Sample plot set) }\end{array}$ & $\begin{array}{c}\text { Liczba } \\
\text { powierzchni } \\
\text { próbnych } \\
\text { (Sample plot } \\
\text { count) }\end{array}$ & $\begin{array}{c}\text { Drewno martwe } \\
\text { stojące } \\
\text { (Standing } \\
\text { deadwood) }\end{array}$ & $\begin{array}{c}\text { Drewno martwe } \\
\text { leżące } \\
\text { (Lying } \\
\text { deadwood) }\end{array}$ & $\begin{array}{c}\text { Drewno martwe } \\
\text { razem } \\
\text { (Total deadwood) }\end{array}$ \\
\hline $\begin{array}{l}\text { WISL (II cykl) - wszystkie klasy wieku } \\
\text { (NFI2 - all age classes) }\end{array}$ & 15414 & 3,32 & 4,56 & 3,00 \\
\hline $\begin{array}{l}\text { WISL (II cykl) - od II klasy wieku } \\
\text { (NFI2 - from age class II upwards) }\end{array}$ & 11601 & 3,46 & 3,90 & 3,16 \\
\hline $\begin{array}{l}\text { WISL (III cykl) - wszystkie klasy wieku } \\
\text { (NFI3 - all age classes) }\end{array}$ & 16930 & 3,54 & 3,60 \\
\hline $\begin{array}{l}\text { WISL (III cykl) - od II klasy wieku } \\
\text { (NFI3 - from age class II upwards) }\end{array}$ & 12371 & 3,86 & 2,86 & 2,64 \\
\hline $\begin{array}{l}\text { PUL - od II klasy wieku } \\
\text { (FMP inventory - from age class II } \\
\text { upwards) }\end{array}$ & 61672 & 1,55 & 1,59 & 1,25 \\
\hline
\end{tabular}

korelacji Pearsona dla drewna martwego traktowanego łącznie wyniósł $r=0,55$ (dla drewna martwego stojącego: $r=0,44$; dla drewna martwego leżącego: $r=0,52$ ). Po odrzuceniu skrajnych wartości (wartość $\log 10(\mathrm{x})<0,5$ ), współczynniki korelacji $r$ wyniosły: łącznie - 0,65, stojące $-0,53$, leżące $-0,59$.

Dla wszystkich 229 nadleśnictw łącznie (tylko grunty Lasów Państwowych), inwentaryzacja PUL wykazała mniejszą zasobność drewna martwego w porównaniu do wyników 
z III cyklu WISL, szczególnie w odniesieniu do drewna martwego stojącego (Tab. 1, Ryc. 8). Należy jednak zauważyć, że w II cyklu WISL szacunek zasobności drewna martwego leżącego był znacząco niższy niż w III cyklu czy w inwentaryzacji PUL.

Jednocześnie szacunek zasobów drewna martwego w przypadku inwentaryzacji PUL obarczony był mniejszym błędem, przede wszystkim ze względu na znacznie większą liczbę powierzchni próbnych, na których było mierzone drewno martwe (Tab. 2, Ryc. 2, 8).

\section{Zasoby drewna martwego w Polsce}

Szacowane na podstawie WISL zasoby drewna martwego w lasach w Polsce wynoszą w sumie ok. 78,8 $\mathrm{mln} \mathrm{m}^{3}$ (Tab. 3). Stanowi to 3\% zasobów drewna na pniu. Całkowite zasoby drewna martwego, oszacowane na podstawie danych z powierzchni próbnych na zakończenie III cyklu WISL (lata 2015-2019), przedstawia tabela 3 i rycina 9. W wartościach bezwzględnych największe zasoby drewna martwego występują w lasach w zarządzie PGL LP, co wiąże się z największym udziałem powierzchni tej formy własności w całkowitej powierzchni lasów w Polsce (76,9\%). Jednakże lasy PGL LP charakteryzują się stosunkowo niską zasobnością względną drewna martwego $\left(8,51 \mathrm{~m}^{3} / \mathrm{ha}\right)$. Jeszcze mniejsza zasobność obserwowana jest $\mathrm{w}$ lasach prywatnych $\left(6,28 \mathrm{~m}^{3} / \mathrm{ha}\right)$, przy ich udziale powierzchniowym wynoszącym 19,3\%. Z kolei lasy Skarbu Państwa w parkach narodowych stanowią jedynie 2\% powierzchni wszystkich lasów, ale charakteryzują się znacznie wyższą miąższością drewna martwego, sięgająca 42,48 $\mathrm{m}^{3} /$ ha. Pozostałe formy własności występują incydentalnie i nie wpływają znacząco na zasoby drewna martwego.

Tabela 3. Całkowite zasoby drewna martwego w Polsce na podstawie WISL 2015-2019

Table 3. Total deadwood stock in Poland, based on NFI 2015-2019

\begin{tabular}{|c|c|c|c|c|c|c|c|}
\hline \multirow[t]{2}{*}{$\begin{array}{l}\text { Zbiór powierzchni próbnych } \\
\text { (Sample plot set) }\end{array}$} & \multirow[t]{2}{*}{$\begin{array}{c}\text { Udział } \\
\text { powierzchni } \\
\text { formy własności } \\
\text { (Area share of } \\
\text { ownership type) } \\
\%\end{array}$} & \multicolumn{2}{|c|}{$\begin{array}{c}\text { Drewno martwe } \\
\text { stojące } \\
\text { (Standing } \\
\text { deadwood) }\end{array}$} & \multicolumn{2}{|c|}{$\begin{array}{c}\text { Drewno martwe } \\
\text { leżące } \\
\text { (Lying deadwood) }\end{array}$} & \multicolumn{2}{|c|}{$\begin{array}{c}\text { Drewno martwe } \\
\text { razem } \\
\text { (Total deadwood) }\end{array}$} \\
\hline & & $\mathrm{m}^{3}$ & $\mathrm{~m}^{3} / \mathrm{ha}$ & $\mathrm{m}^{3}$ & $\mathrm{~m}^{3} / \mathrm{ha}$ & $\mathrm{m}^{3}$ & $\mathrm{~m}^{3} / \mathrm{ha}$ \\
\hline Ogółem (Total) & 100 & 39398445 & 4,26 & 39364241 & 4,25 & 78762686 & 8,51 \\
\hline $\begin{array}{l}\text { W zarządzie Lasów Państwowych } \\
\text { (State Forests Holding) }\end{array}$ & 76,9 & 27806601 & 3,91 & 30408801 & 4,27 & 58215402 & 8,18 \\
\hline $\begin{array}{l}\text { W zarządzie Parków Narodowych } \\
\text { (National Parks) }\end{array}$ & 2,0 & 3313518 & 17,84 & 4575799 & 24,64 & 7889317 & 42,48 \\
\hline $\begin{array}{l}\text { Inne Skarbu Państwa } \\
\text { (Other State Treasury) }\end{array}$ & 0,6 & 420381 & 7,75 & 271238 & 5,00 & 691619 & 12,74 \\
\hline Gminne (Municipal) & 0,9 & 465309 & 5,51 & 380282 & 4,51 & 845591 & 10,02 \\
\hline $\begin{array}{l}\text { W Zasobie Własności Rolnej } \\
\text { Skarbu Państwa } \\
\text { (Agricultural Stock of the State } \\
\text { Treasury) }\end{array}$ & 0,3 & 198306 & 7,18 & 172893 & 6,26 & 371199 & 13,45 \\
\hline Prywatne (Private) & 19,3 & 7381863 & 4,13 & 3848925 & 2,15 & 11230788 & 6,28 \\
\hline
\end{tabular}




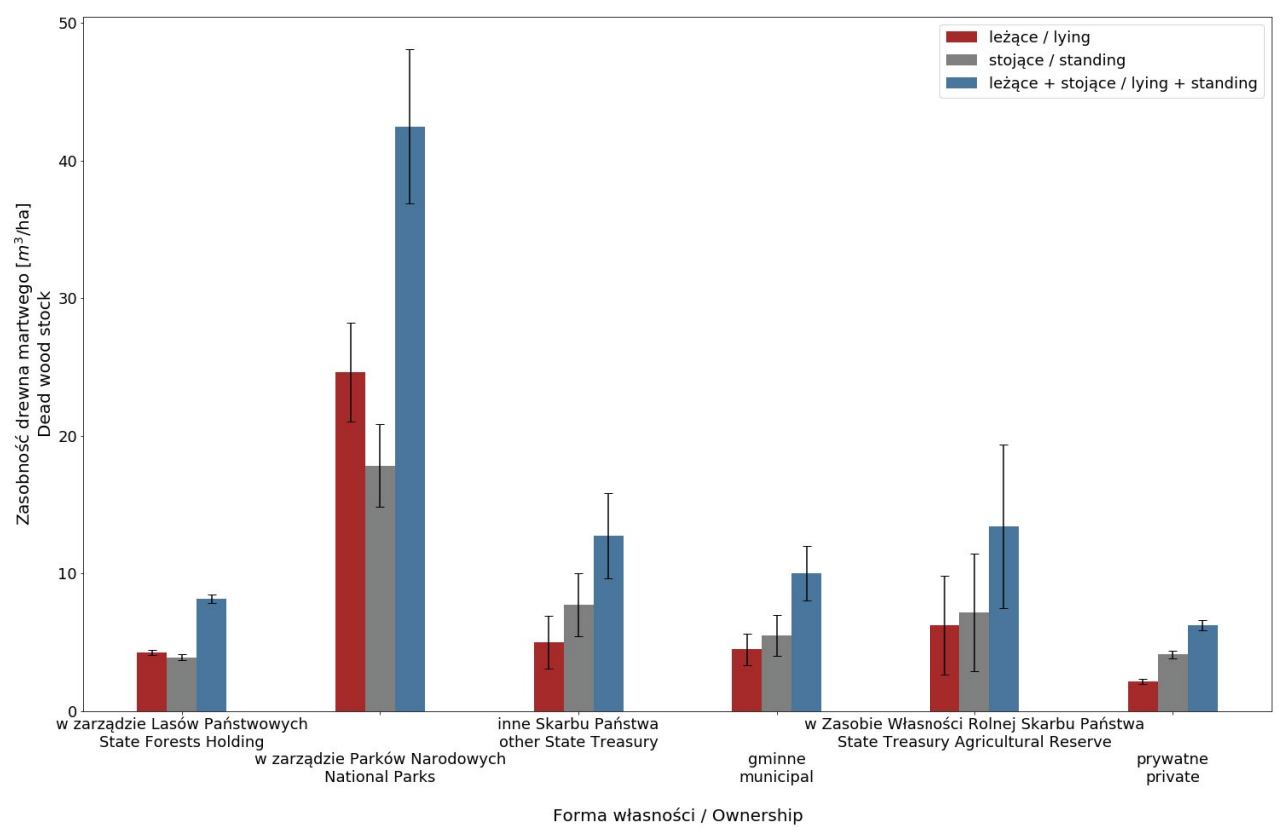

Ryc. 9. Zasobność drewna martwego na podstawie danych z WISL (2015-2019) w lasach różnych form własności Fig. 9. Deadwood stock based on data from the NFI (2015-2019), by form of forest ownership

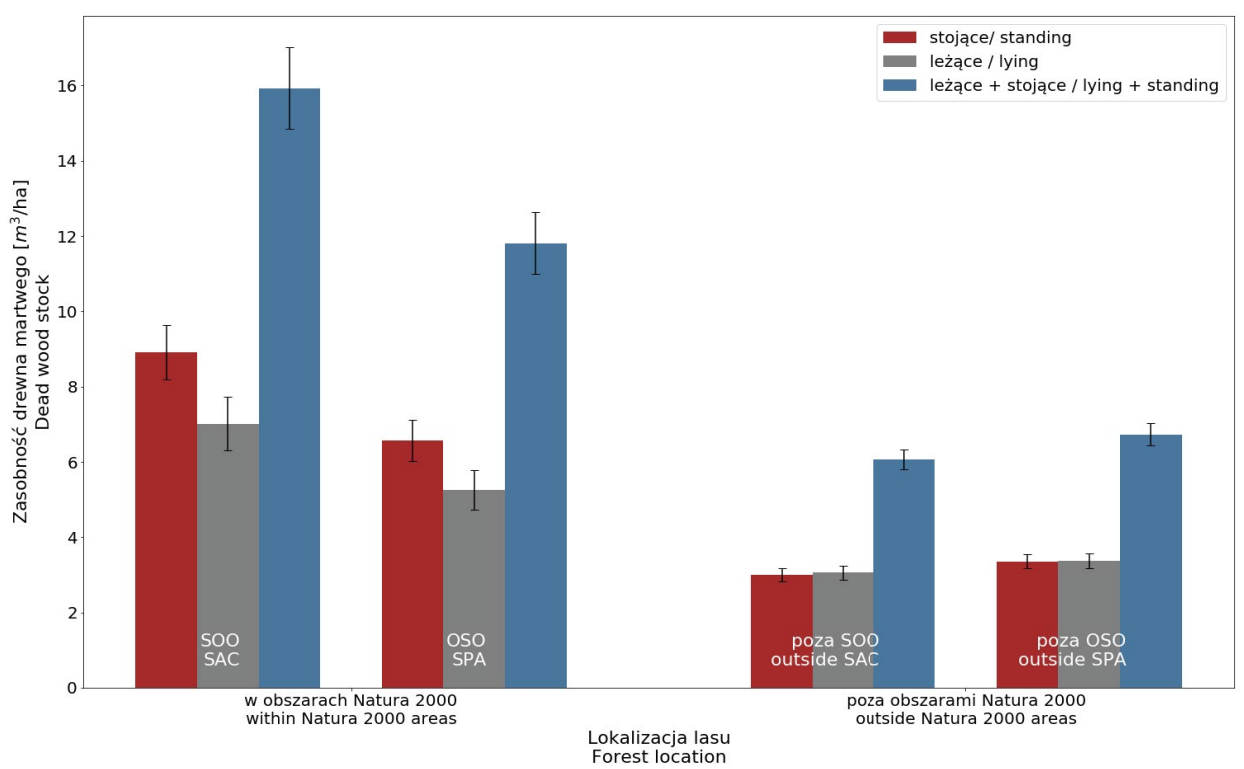

Ryc. 10. Porównanie zasobności drewna martwego na podstawie danych z WISL (2015-2019) w lasach w obszarach i poza obszarami Natura 2000

Fig. 10. Comparison of deadwood stock, based on NFI (2015-2019) data from forests inside and outside Natura 2000 areas 
Porównanie zasobów drewna martwego, oszacowanego na podstawie powierzchni próbnych WISL w lasach w obszarach Natura 2000 i poza nimi przedstawia rycina 10. Zaobserwowano wyraźnie większą zasobność drewna martwego, zarówno stojącego, jak i leżącego, w lasach usytuowanych w specjalnych obszarach ochrony (SOO) siedlisk, w stosunku do obszarów ochrony specjalnej (OSO, tzw. obszary ptasie). Zarówno w lasach leżących w obszarach SOO, jak i OSO, zasobność drewna martwego jest znacząco wyższa niż w lasach leżących poza tymi obszarami.

\section{Zmiany zasobów drewna martwego}

Analiza zasobów drewna martwego w wynikach WISL (Ryc. 11) wskazuje, że w ciągu ostatniej dekady proporcje w zasobach drewna martwego pomiędzy formami własności kształtowały się w zbliżony sposób. Zasobność drewna martwego była stale najniższa w lasach

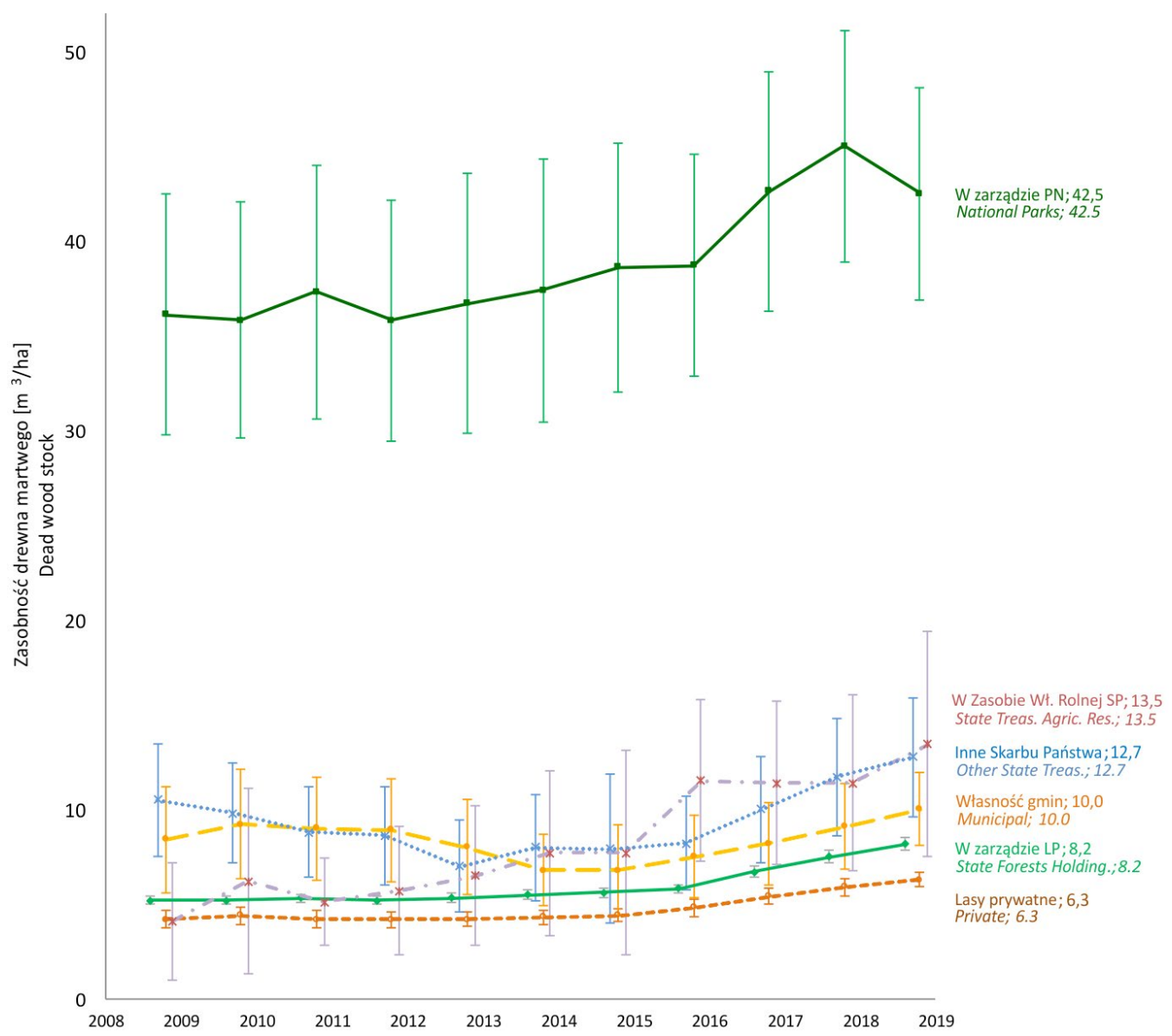

Ryc. 11. Zmiany zasobności drewna martwego na podstawie danych z WISL

Fig. 11. Changes in deadwood stock, based on NFI data 
prywatnych, a nieco wyższa w Lasach Państwowych. Fluktuacje zasobności w innych, mało licznych formach własności nie wykraczały poza przedział ufności. Lasy Skarbu Państwa w parkach narodowych odbiegają pod tym względem od innych lasów, trwale utrzymując zasobność drewna martwego 5-8 razy wyższą niż w innych formach własności. W ostatnich latach można zaobserwować nieznaczny wzrost zasobności drewna martwego.

\section{DYSKUSJA}

\section{Porównanie wyników dotyczących drewna martwego z inwentaryzacji urządzeniowej i WISL}

Metodyki inwentaryzacji drewna martwego stosowane w pracach urządzeniowych oraz w WISL różnią się w znaczący sposób. Wpływa to na istotne różnice w wynikach oszacowania miąższości i zasobności drewna martwego pomiędzy tymi tymi dwoma inwentaryzacjami (Tab. 1). Podstawową różnicą jest wyłączenie z inwentaryzacji PUL drzewostanów poniżej II klasy wieku (poniżej 20 lat), podczas gdy w WISL powierzchnie próbne są zakładane systematycznie we wszystkich drzewostanach. Ponadto, od III cyklu WISL stosowane są powierzchnie próbne o stałej wielkości $400 \mathrm{~m}^{2}$, podczas gdy w inwentaryzacji urządzeniowej taka wielkość jest stosowana dopiero od V klasy wieku (powyżej 80 lat). Porównanie rozkładów liczby fragmentów drewna martwego w klasach długości pokazuje istotne różnice w częstości występowania fragmentów drewna martwego o różnej długości, spowodowane odmiennymi algorytmami zaliczania fragmentów drewna martwego do powierzchni próbnej. Szczególnie wyraźnie widać mniejszą reprezentację fragmentów drewna stojącego o długości 0-15 m w inwentaryzacji PUL (Ryc. 5), co koreluje z niższym oszacowaniem zasobności tej klasy drewna martwego (Tab. 1). Nie można także wykluczyć wpływu faktu, że pomiary WISL są wykonywane w okresie 5 lat, a pomiary dla PUL w ciągu jednego sezonu. Co więcej, analizowane dane z PUL pochodziły z lat 2012-2019, a z WISL z lat 2010-2014 (II cykl) oraz 2015-2019 (III cykl), a wyższy szacunek zasobów drewna martwego z WISL w III cyklu może być wynikiem ujawnienia się zmian w zasobności drewna martwego, zachodzących w czasie (Ryc. 8; patrz też niżej - dyskusja na temat dynamiki zasobów drewna martwego).

Porównanie średniej zasobności drewna martwego, obliczonej dla poszczególnych nadleśnictw na podstawie pomiarów z PUL i WISL pokazały, że istnieje pomiędzy tymi wynikami pewna korelacja, aczkolwiek nierzadkie są znaczne rozbieżności (Ryc. 7). Wskazywać to może na ograniczoną porównywalność obu stosowanych w Polsce metod inwentaryzacji drewna martwego. Stopień korelacji może zależeć od kilku nakładających się czynników. Po pierwsze, siatki powierzchni próbnych PUL i WISL nie pokrywają się ze sobą. W związku z tym, że drewno martwe nie jest na ogół rozmieszczone równomiernie w przestrzeni, próby statystyczne charakteryzują się dużą zmiennością. Po drugie, występują wspomniane wyżej różnice momentu wykonywania inwentaryzacji. Po trzecie, omawiane metodyki inwentaryzacji drewna martwego różnią się znacznie liczbą zakładanych powierzchni próbnych, przy czym rozrzut dla nadleśnictwa jest znacznie mniejszy w przypadku WISL, podczas gdy w inwentaryzacji PUL liczba zakładanych powierzchni dla jednego nadleśnictwa może 
różnić się nawet o pół rzędu wielkości (Ryc. 2). Wpływa to na dokładność inwentaryzacji. Można domniemywać, że błąd szacowania miąższości drewna martwego w inwentaryzacji PUL może się znacząco różnić pomiędzy nadleśnictwami.

\section{Zasoby drewna martwego w Polsce}

W leśnictwie krajów Europy Środkowej głęboko zakorzenione jest stosowanie tradycyjnych praktyk gospodarki leśnej, niektóre z nich mają na celu zmniejszenie niejednorodności lasów, która jest jednak kluczowym czynnikiem wspierającym różnorodność biologiczną (VítKovÁ i in. 2018). Stosowany w Polsce od trzech dekad paradygmat trwale zrównoważonej, wielofunkcyjnej gospodarki leśnej w coraz większym stopniu bierze pod uwage potrzeby związane $\mathrm{z}$ ochroną i zwiększaniem różnorodności biologicznej oraz pozaprodukcyjne funkcje lasu. Wpływa to także na sytuację w zakresie retencji drewna martwego w lasach.

Najmniejsza zasobność drewna martwego obserwowana jest w lasach prywatnych (Ryc. 9), prawdopodobnie ze względu na znaczne rozdrobnienie gospodarstw leśnych tej formy własności i wykorzystywanie drewna martwego lub uszkodzonego na własne potrzeby właścicieli (np. na opał). Największa zasobność drewna martwego występuje w lasach parków narodowych (powyżej $40 \mathrm{~m}^{3} / \mathrm{ha}$ ), ze względu na stosowane w nich reżimy ochronne i ograniczenie dostępu. W innych badaniach, średnią zasobność drewna martwego na obszarach ściśle chronionych w Polsce obliczono na $172 \mathrm{~m}^{3} /$ ha (BuJoczeK i in. 2018), przy czym należy pamiętać, że obszary ściśle chronione w parkach narodowych stanowią zaledwie od 1 do 64\% ich powierzchni, średnio 22\% (JAMROZY 2014).

Przeciętna zasobność drewna martwego w Lasach Państwowych, które stanowią w większości lasy gospodarcze, wynosi ponad $8 \mathrm{~m}^{3} / \mathrm{ha}$. Wielkość ta jest uznawana za wystarczającą w lasach strefy umiarkowanej dla gatunków zwierząt związanych z drzewami, w tym ptaków, natomiast według części doniesień, jest zbyt mała dla pewnych grup organizmów, np. saproksylicznych, pewnych gatunków grzybów i innych ksylobiontów (MÜLLER \& BÜTLER 2010).

Porównanie zasobności drewna martwego na obszarach Natura 2000, które w Polsce sa jedną z ustawowych form ochrony przyrody, wykonane na terenie Lasów Państwowych, wykazało, że zarówno obszary o specjalnym znaczeniu dla Wspólnoty (tzw. obszary siedliskowe, SOO), jak i obszary specjalnej ochrony ptaków (OSO) charakteryzują się większą zasobnością drewna martwego niż lasy poza nimi (Ryc. 10). Do przyczyn tego stanu rzeczy należy zaliczyć fakt, że obszary Natura 2000 były tworzone na terenach cennych przyrodniczo, o bardziej złożonych ekosystemach i wyższej bioróżnorodności, a także wprowadzone są tam ograniczenia w rodzaju i zakresie działań gospodarczych oraz innej ingerencji człowieka.

\section{Zmiany zasobów drewna martwego}

Zaobserwować można stały, choć niezbyt dynamiczny trend zwiększania się zasobności drewna martwego w lasach wszystkich form własności (Ryc. 11). Przyśpieszenie tego procesu zaobserwowano w ostatnich trzech latach (2016-2018), co może odzwierciedlać 
niekorzystne procesy zachodzące w lasach, związane m.in. ze zmianami klimatycznymi, szczególnie obniżenie poziomu wód gruntowych, wiatrołomy i narastające pojawianie się owadzich szkodników wtórnych. Należy pamiętać, że wyniki WISL dla danego roku oparte są na pomiarach wykonanych $\mathrm{w}$ ciągu pięciu lat, można więc przypuszczać, że proces zwiększania ilości martwego drewna w lasach ma w rzeczywistości większą dynamikę, która ujawni się w pomiarach w latach następnych.

$\mathrm{Na}$ chwilę obecną nie jest możliwe oszacowanie dynamiki zmian drewna martwego w Lasach Państwowych na podstawie inwentaryzacji taksacyjnej, gdyż drewno martwe jest mierzone na taksacyjnych powierzchniach próbnych dopiero od 2011 r. i nie ma jeszcze danych tworzących szeregi czasowe.

Podziękowania. Bank Danych o Lasach i Wielkoobszarowa Inwentaryzacja Stanu Lasów są finansowane przez Dyrekcję Generalną Lasów Państwowych ze środków funduszu leśnego.

Autor wyraża podziękowanie pani Longinie Sobolewskiej za czas poświęcony na konsultacje w zakresie struktury danych i metodyki obliczeń stosowanych w WISL, a także dwóm anonimowym recenzentom za cenne uwagi i wskazówki.

\section{LITERATURA}

BoBIEC A. 2002. Living stands and dead wood in the Białowieża forest: suggestions for restoration management. - Forest Ecology and Management 165(1-3): 125-140.

Bobiec A., van der Burgt H., Meijer K., Zuyderduyn C., Haga J. \& Vlaanderen B. 2000. Rich deciduous forests in Białowieża as a dynamic mosaic of developmental phases: premises for nature conservation and restoration management. - Forest Ecology and Management 130(1-3): 159-175.

Bujoczek L., Szewczyk J. \& Bujoczek M. 2018. Deadwood volume in strictly protected, natural, and primeval forests in Poland. - European Journal of Forest Research 137(4): 401-418.

BULIGL 2017. Założenia do oprogramowania w zakresie przetwarzania danych oraz raportów charakteryzujących stan lasów. Wzory raportów charakteryzujących stan lasów. Wersja 2, uwzględniająca zmiany metodyki obliczeń dokonane w III cyklu WISL. Biuro Urządzania Lasu i Geodezji Leśnej, Warszawa.

FALIŃSKI J. B. 1978. Uprooted trees, their distribution and influence in the primeval forest biotope. - Vegetatio 38(3): 175-183.

FAO 2012. FRA 2015 Terms and Definitions. - Forest Resources Assessment Working Paper 180: 1-31. http://www.fao.org/3/ap862e/ap862e00.pdf (dostęp: 16.01.2020).

GUS 2019. Rocznik Statystyczny Leśnictwa 2019. s. 372. Główny Urząd Statystyczny, Warszawa.

Harmon M. E., Franklin J. F., Swanson F. J., Sollins P., Gregory S. V., Lattin J. D., Anderson N. H., Cline S. P., Aumen N. G., Sedell J. R., Lienkaemper G. W., Cromack K. Jr. \& Cummins K. W. 1986. Ecology of coarse woody debris in temperate ecosystems. - W: A. MACFADYEN \& E. D. FORD (red.), Advances in ecological research 15: 133-302. Academic Press, Inc., Orlando, FL.

IBL 2010. Instrukcja wykonywania wielkoobszarowej inwentaryzacji stanu lasu. s. 66. Instytut Badawczy Leśnictwa, Warszawa. https://www.buligl.pl/documents/10192/278026/Instrukcja+WISL+2010-2014. pdf/24d778cc-cd71-4b97-8ebd-0560037c948d (dostęp: 16.01.2020).

IBL 2014. Instrukcja wykonywania wielkoobszarowej inwentaryzacji stanu lasu. s. 62. Instytut Badawczy Leśnictwa, Sękocin Stary. https://www.buligl.pl/documents/10192/278026/Instrukcja+WISL+2015-2019.pdf/a2b24061-be31-4c4e-bbd0-ea24caa405d8 (dostęp: 21.09.2019). 
JAMROZY G. (red). 2014. Ssaki polskich parków narodowych: drapieżne, kopytne, zajęczaki i duże gryzonie. s. 432. Instytut Bioróżnorodności Leśnej, Wydział Leśny Uniwersytetu Rolniczego w Krakowie, Magurski Park Narodowy, Kraków - Krempna.

KŁapeć B., Bruchwald A., Stępień E., Porter B., Dudek A., Tomusiak R., Dudzińska M., Michalak K., Wróblewski L., Mirż G., Wojtan R., Ciosmak P., Wójcik L. \& Matosek U. 2005. Opracowanie metod określania struktury sortymentowej drzewostanów z wykorzystaniem komputerowej bazy danych nadleśnictwa. Maszynopis sprawozdania końcowego dla DGLP. Szkoła Główna Gospodarstwa Wiejskiego, Warszawa.

KRAJICK K. 2001. Defending deadwood. - Science 293: 1579-1581.

MÜLLER J. \& BÜTLER R. 2010. A review of habitat thresholds for dead wood: a baseline for management recommendations in European forests. - European Journal of Forest Research 129(6): 981-992.

PGL LP 2012. Instrukcja urządzania lasu. Cz. 1. Instrukcja sporządzania projektu planu urządzenia lasu dla nadleśnictwa. s. 287. Centrum Informacyjne Lasów Państwowych, Warszawa.

PGL LP 2015. Wielkoobszarowa Inwentaryzacja Stanu Lasów. Wyniki II cyklu (lata 2010-2014). s. 433. Oficyna Wydawnicza FOREST, Sękocin Stary. https://www.buligl.pl/documents/10192/304500/ WISL-2010-2014.pdf/11a4e1ee-8f22-4ea3-92c8-52d43186db61 (dostęp: 16.01.2020).

PGL LP 2019. Raport o stanie lasów w Polsce 2018. s. 101. Państwowe Gospodarstwo Leśne Lasy Państwowe, Warszawa. https://www.bdl.lasy.gov.pl/portal/Media/Default/Publikacje/raport_o_stanie_ lasow_2018.pdf (dostęp: 16.01.2020).

Puletti N., Canullo R., Mattioli W., Gawryś R., Corona P. \& Czerepko J. 2019. A dataset of forest volume deadwood estimates for Europe. - Annals of Forest Science 76(3): 68. http://link.springer. com/10.1007/s13595-019-0832-0 (dostęp: 16.01.2020).

RONDEUX J. \& SANCHEZ C. 2010. Review of indicators and field methods for monitoring biodiversity within national forest inventories. Core variable: Deadwood. - Environmental Monitoring and Assessment 164(1-4): 617-630.

SOLON J. 2002. Ekologiczna rola martwego drewna w ekosystemach leśnych - dyskusja wybranych zagadnień w świetle literatury. - W: A. Breymeyer, M. Degórski, E. Roo-ZielińsKa, J. Solon \& J. Wolski (red.), Podstawy trwałego i zrównoważonego zagospodarowania lasów w Leśnych Kompleksach Promocyjnych. Martwe drewno i jego funkcje ekologiczne w lasach zagospodarowanych i rezerwatach wybranych LKP. Sprawozdanie z III etapu, s. 15. Instytut Badawczy Leśnictwa, Sękocin Las.

SzYmkiEwicz B. 2001. Tablice zasobności i przyrostu drzewostanów ważniejszych gatunków drzew leśnych. s. 175. Państwowe Wydawnictwo Rolnicze i Leśne, Warszawa.

TalarczyK A. 2014. National forest inventory in Poland. - Baltic Forestry 20(2): 333-340.

TAXus IT 2020. Taksator. Państwowe Gospodarstwo Leśne Lasy Państwowe. http://www.zilp.lasy.gov.pl/ taksator1 (dostęp: 16.01.2020).

Ustawa 1991. Ustawa z dnia 28 września 1991 r. o lasach (Dz. U. 1991 nr 101, poz. 444).

VítKová L., BaČE R., KuUČUKov P. \& Svoboda M. 2018. Deadwood management in Central European forests: Key considerations for practical implementation. - Forest Ecology and Management 429: 394-405.

WoLsKi J. 2003. Martwe drewno w lesie: ocena zapasu i propozycje postępowania. - Prace Instytutu Badawczego Leśnictwa, Seria A 2: 23-45.

Woodall C. W., Rondeux J., Verkerk P. J. \& StÅHL G. 2009. Estimating dead wood during national forest inventories: a review of inventory methodologies and suggestions for harmonization. - Environmental Management 44(4): 624-631. 
Woodall C. W., Monleon V. J., Fraver S., Russell M. B., Hatfield M. H., Campbell J. L. \& Domke G. M. 2019. The downed and dead wood inventory of forests in the United States. - Scientific Data 6(1): 180303. DOI: 10.1038/sdata.2018.303.

ZielonKa T. \& NiKLasson M. 2001. Dynamics of dead wood and regeneration pattern in natural spruce forest in the Tatra Mountains, Poland. - Ecological Bulletins 49: 159-163.

\section{SUMMARY}

\section{Introduction}

Deadwood plays a key role in many processes and functions of forest ecosystems, and for this reason its resources should be monitored (HARMON et al. 1986; KRAJICK 2001; SOLON 2002). The first inventory and monitoring of deadwood took place in the 1960s, when the emergence of modern fire protection methods required quick field assessments of the amount of fire-fuel in the forest. These inventories were not done systematically in most countries. The first national deadwood inventories were initiated only when comprehensive national forest monitoring initiatives were launched in the 1990s (e.g. the Santiago Declaration) and greenhouse gas reporting requirements for land use, land use change, and forestry (LULUCF) sector were promulgated under the United Nations Framework Convention on Climate Change (WoODALL et al. 2019). In the first decade of this century, at least 30 countries included deadwood in their national forest inventories (WoOdall et al. 2009). Their goal was not only to assess fire risks but also to estimate the carbon balance and to monitor biodiversity (RONDEUX \& SANCHEZ 2010).

Until recently, research on the occurrence of deadwood in Polish forests was done unsystematically, often in areas of high natural value such as the Białowieża Forest (FALIŃsKi 1978; BoBIEC et al. 2000; BoBIEC 2002) and mountainous regions (ZIELONKA \& NIKLASSON 2001), although analyses of commercially exploited forests were also performed (WOLSKI 2003). Inventorying on a larger scale began at the beginning of the 21 st century. Currently, deadwood in forested areas is systematically inventoried as part of two independent activities: (1) as part of stand inventories during the preparation of forest district management plans in the forests of the State Treasury managed by the State Forests Holding (SFH), and (2) as part of the National Forest Inventory (NFI) in forests under all forms of ownership. In addition, Poland is a member of the International Co-operative Programme on Assessment and Monitoring of Air Pollution Effects on Forests (ICP Forests); data for this program are collected from some NFI sample plots, because the NFI measuring grid is based on the ICP Forests Level I grid (TALARCZYK 2014; PULETTI et al. 2019).

The aims of the present work were (1) to familiarize the reader with the methodology of Poland's two most important national inventories of deadwood, and (2) to present and compare the results of these inventories in SFH forest districts carried out between 2013 and 2019.

\section{Materials and methods}

\section{Inventorying deadwood during preparation of a forest management plan}

During the preparation of a forest management plan for a forest district, an inventory of forest resources is carried out by a sample plot method. Stands aged 21 years and older are inventoried if the average height of the dominant species is $7 \mathrm{~m}$ or more. Measurements are made in randomly sampled circular plots. Sample plot size varies from 0.005 ha to 0.05 ha, depending on the age of the dominant species. The length of a deadwood fragment is measured only down to the point at which its diameter measures $70 \mathrm{~mm}$. In principle, only dead trees or deadwood fragments that can be clearly identified as originating from within the sample plot are measured. Parts of dead trees or deadwood that are outside the sample plot are also subject to measurement if their origin can be clearly assigned to the sample plot. Lying deadwood 
classified as originating from the sample plot is measured if its diameter at the thicker end exceeds $100 \mathrm{~mm}$ over bark (PGL LP 2012).

Deadwood in stand inventory sample plots has been measured since 2012. A set of 229 available inventory databases has been used in this work. The total area of forests managed by the SFH is 7,114,617.67 ha (GUS 2019). In total, data for 53.3\% of the number of forest districts have been analysed (229 out of 430). Their area amounts to 3,989,575 ha, which is $56.0 \%$ of the area of all forests under the management of the $\mathrm{SFH}$. The locations of the analysed forest districts are presented in Figure 1.

\section{Inventorying deadwood in the National Forest Inventory}

As part of the NFI, measurements are made in circular sample plots distributed in clusters on a regular $4 \times 4 \mathrm{~km}$ grid (TALARCZYK 2014). In the NFI1 (2005-2009) and NFI2 (2010-2014) series, sample plot size ranged from 200 to $500 \mathrm{~m}^{2}$, depending on stand age (IBL 2010). Since the start of NFI3 (2015-2019), all sample plots cover $400 \mathrm{~m}^{2}$ (IBL 2014). Only deadwood within the sample plot is inventoried; for lying trees and wood fragments that intersect the sample plot border, only their parts located within the plot are measured, if their minimum length is $50 \mathrm{~cm}$ and their diameter at the thicker end is greater than $100 \mathrm{~mm}$ over bark ( $80 \mathrm{~mm}$ under bark). The length of deadwood fragments is measured to the point where their diameter over bark is $70 \mathrm{~mm}$ (50 mm under bark), or to the sample plot border (IBL 2014).

Deadwood measurements have been carried out as part of the NFI since the beginning of this project in 2005. In NFI1 (2005-2009), 28,909 sample plots were established; in NFI2 (2010-2014), 29,523 (PGL LP 2015); and in NFI3 (2015-2019), 30,578 (unpublished data).

Data on the area of forests covered by the Natura 2000 network are available only for forests managed by the SFH: $2,891,000$ ha (38.0\% of the total SFH area), including 133 Special Protection Areas (SPA) covering 2,227,000 ha $(29.1 \%)$ and 708 Special Areas of Conservation (SAC) covering 1,663,000 ha (21.9\%) (PGL LP 2019). The total forested area of the SFH as of 31 December 2018 was 7,114,617.67 ha (GUS 2019). Due to the lack of comparable data for other forms of ownership, deadwood resources in Natura 2000 areas were analysed only for forests managed by the SFH.

\section{Estimation methodology}

In a stand-wise inventory, calculations of the thickness of individual deadwood fragments employ the Taksator software package (TAXUS IT 2020), and in the NFI the NFI software package (BULIGL 2017). Deadwood stock $\left(\mathrm{m}^{3} / \mathrm{ha}\right)$ in a single sample plot has been calculated as a simple arithmetic mean. Total deadwood volume has been calculated as the weighted mean of sample plot stock multiplied by the total forest area of the domain. In a stand-wise inventory, the weighting factor is sample plot size, while in the NFI the weighting factor is relative sample plot size. The standard percentage error of estimation has been calculated according to Equation 3.

\section{Changes in deadwood stock}

Deadwood estimates have been available for Poland since the last year of the NFI1 (2009). Because the NFI is carried out on a continuous basis, with $20 \%$ of the sample plots being inventoried each year, the deadwood estimates can be updated annually.

\section{Data analysis}

The data have been analysed in PostgreSQL 11 (stand-wise inventory) and Microsoft SQL Server 2014 (NFI), using R version 3.50 (www.r-project.org) and Python version 3.6.8 (www.python.org), in the RStudio IDE (rstudio.com) and Jupyter Notebook (jupyter.org) environments. The plots have been prepared using the following software packages: ggplot2 version 3.2.1 (ggplot2.tidyverse.org), pandas version 0.25 (pandas.pydata.org), matplotlib version 3.1.2 (matplotlib.org) and seaborn version 0.9.0 (seaborn. pydata.org). 


\section{Results}

\section{Comparison of deadwood inventory results from the NFI and stand-wise inventories}

The results of the deadwood inventory for 229 SFH districts have been compared to the results obtained from the NFI sample plots established in the analysed forest districts of the SFH. To increase the comparability of results, for NFI results only the data from sample plots established in stands from age class II were used in the analysis (to match the dataset from the stand-wise inventories). Figure 2 compares the number of sample plots established in the area of a given forest district. In stand-wise inventories, deadwood was measured in 269 plots per district on average (from 90 to 607, median 231). In the NFI, the sample plot counts per district were much lower, 48 on average (from 2 to 96, median 48). In stand-wise inventories, deadwood fragments are classified according to their origin and appearance. The distribution of their length is presented in Figure 3, and the distribution of their diameter in Figure 4. Figure 5 compares the distribution of deadwood in length classes. The number of all inventoried deadwood fragments lying in the area of the analysed forest districts is higher in the stand-wise inventories than in the NFI inventory, especially for the 0-3 m length class, and to a lesser extent for $10 \mathrm{~m}$ and above, but for standing deadwood more fragments were recorded in the NFI inventory, especially for length up to $15 \mathrm{~m}$. No correlation was found between the number of fragments and the abundance of deadwood in a sample plot (Fig. 6). There was a positive correlation between the average abundance of deadwood for a given number of fragments and the number of fragments of deadwood (using a second-degree polynomial), primarily for standing deadwood $(r=0.64)$ and total deadwood $(r=0.73)$; the correlation was much weaker for lying deadwood $(r=0.43)$.

Figure 7 compares deadwood estimates for individual forest districts. A Pearson correlation coefficient of $r=0.55$ was found for total deadwood ( 0.44 for standing deadwood, 0.52 for lying deadwood). For comparison, deadwood estimates for all 229 forest districts (only SFH land) are presented in Table 1 and Figure 8. Content of deadwood was lower in stand-wise inventories than in the NFI, especially for standing deadwood. Deadwood estimation for stand-wise inventories was burdened with a smaller error, primarily due to the much larger number of sample plots in which deadwood was measured (see Tab. 2, Fig. 2).

\section{Deadwood stock in Poland}

Based on the NFI, deadwood in Polish forests is estimated at 78,8 $\mathrm{mln}^{3}$ (Tab. 3). This represents $3 \%$ of the total timber growing stock. Total deadwood estimates based on data from sample plots at the end of NFI3 (2015-2019) are presented in Table 3 and Figure 9. Figure 10 compares deadwood resources estimated from NFI sample plots in forests in Natura 2000 areas and outside them. Deadwood, both standing and lying, was clearly more abundant in forests in SAC than in SPA. In both types of area the density of deadwood was significantly higher than in forests outside these areas.

\section{Changes in deadwood stock}

This analysis of deadwood resources in the NFI (Fig. 11) indicates that over the past decade the relative proportion of deadwood resources between ownership forms has remained approximately constant. The deadwood stock has been consistently lowest in private forests, and slightly higher in state-owned forests. For other small-area forms of ownership the deadwood stock has fluctuated within the confidence interval. State Treasury forests within national parks differ in this respect from other forests, permanently maintaining deadwood content 5-8 times higher than under other forms of ownership. In recent years a slight increase in the volume of deadwood has been observed in all forests.

\section{Discussion}

\section{Comparison of deadwood estimates from stand-wise inventories and from the NFI}

The deadwood inventory methods differ significantly between stand-wise inventories and the NFI, and thus in their respective results from deadwood estimation (Tab. 1). The main difference is exclusion of stands below age class II (below 20 years) from the stand-wise inventories, while the NFI established 
sample plots in all forest stands. Moreover, since NFI3, sample plots with a uniform size of $400 \mathrm{~m}^{2}$ have been used, while in stand-wise inventories this size is applied only from age class V (above 80 years). A comparison of the distribution of the number of deadwood fragments in length classes shows significant differences in the frequency of occurrence of deadwood fragments of different lengths, due to the use of different algorithms for including deadwood fragments in the sample plot. Particularly clear is the smaller representation of standing wood fragments in the 0-15 m length class in stand-wise inventories (Fig. 5), which correlates with a lower estimate for this class of deadwood (Tab. 1). The NFI measurements are carried out over a 5-year period, and the measurements for stand-wise inventories are carried out during one season. Moreover, the analysed stand-wise inventory data came from 2012-2019, while the NFI data came from 2010-2014 (NFI2) and 2015-2019 (NFI3); the higher deadwood estimate in NFI3 may be the result of changes in the abundance of deadwood occurring over time (Fig. 8; see also discussion below on the dynamics of deadwood resources).

This comparison of the average deadwood stock estimated for individual forest districts based on measurements from the stand-wise inventories and the NFI showed a correlation between these results, but significant discrepancies were not uncommon (Fig. 7), suggesting that the two deadwood inventory methods used in Poland are of limited comparability. The degree of correlation may depend on several factors which may overlap in their effect: (1) Sample plots are established at different geographic locations. Since deadwood is generally not evenly distributed geographically, statistical samples exhibit high variability. (2) There are the above-mentioned differences in the timing of the inventories. (3) The discussed deadwood inventory methods differ significantly in the number of sample plots, and their number within a forest district is significantly lower in the NFI, while in the stand-wise inventories the number of plots may differ even by half an order of magnitude (Fig. 2). This affects the accuracy of inventorying. The error in estimating deadwood volume in the stand-wise inventories may vary significantly between forest districts.

\section{Deadwood stock in Poland}

Traditional forestry practices are deeply rooted in Central Europe; some of the practices are aimed at reducing forest heterogeneity, which of course is a key factor supporting biodiversity (VítKovÁ et al. 2018). In the past three decades the paradigm of sustainable multifunctional forest management that has been adopted in Poland has increasingly embraced the imperative to protect and enhance biodiversity and the non-timber functions of forests. This has an effect on retention of deadwood in forests.

Deadwood abundance is the lowest in private forests, probably due to significant fragmentation of forest holdings under this form of ownership as well as the use of dead or damaged wood for the needs of the owners (e.g. fuel). Deadwood is the most abundant in the forests of national parks (over $40 \mathrm{~m}^{3} / \mathrm{ha}$ ), due to their protection regimes and also access restrictions. In other studies the average stock of deadwood in strictly protected areas in Poland was calculated at $172 \mathrm{~m}^{3} / \mathrm{ha}$ (BUJOCZEK et al. 2018), but it should be remembered that strictly protected areas in national parks constitute only $1-64 \%$ of their area, on average $22 \%$ (JAMROZY 2014).

The average deadwood stock in the forests of the SFH, which mostly are forests managed for economic use, is above $8 \mathrm{~m}^{3} / \mathrm{h}$. This amount is considered sufficient in temperate zone forests for tree-related animal species, including birds; according to some reports, however, it is too low for certain groups such as saproxylic organisms, certain fungal species and other xylobionts (MÜLLER \& BÜTLER 2010).

The comparison of deadwood abundance in Natura 2000 areas, which in Poland are one of the statutory forms of nature protection applied in SFH forests, showed that both SAC and SPA have greater abundance of deadwood than forests outside them (Fig. 10). The reasons include the fact that Natura 2000 sites were generally created in areas of high natural value, with more complex ecosystems and higher biodiversity, and that there are restrictions on the type and scope of economic activity and other human interventions.

\section{Deadwood resource dynamics}

There has been a constant though not very dynamic trend of increasing deadwood abundance in forests under all forms of ownership (Fig. 11). It has accelerated in the latest three years (2016-2018), perhaps 
reflecting adverse processes in forests, related to factors such as climate change, lowering of groundwater, windthrow events and increasing damage from secondary insect pests. It should be remembered that the NFI results for a given year are based on measurements taken over five years, so the recorded increase in the amount of deadwood in forests may conceal greater dynamics that will be revealed in subsequent measurement years.

At present it is not possible to estimate the dynamics of change in the deadwood of the SFH forests based on stand-wise inventories, because deadwood has been measured in the sample plots only since 2011, so the data have not yet formed a useful time series.

Wptynęto: 29.01.2020 r.; przyjęto do druku: 18.03.2020 r. 